\title{
Making Full Use of Movie Materials to Teach Literature
}

\author{
Shaojun Duan* \\ School of Foreign Languages \\ Kunming University \\ Kunming, China \\ duanshaojun2709@126.com
}

\begin{abstract}
Nowadays students prefer watching movie versions to reading the literary works in paper products. As a literature teacher, we can make the full use of this situation to arouse students' interests in learning literature and attract them to go back to read the original literary texts if they want to know more details or the difference between movies and the texts. In this paper, an example is provided for teachers to imitate by choosing Charles Dickens' "Great Expectations" and the adapted movie version in 2012 to compare in order to show their differences in characters and plots, As a result, the author of this paper hopes this way of teaching literature can arouse students' interests in learning literature and attract them to go back to read the original literary texts.
\end{abstract}

Keywords-literature teaching; Great Expectations; the adapted film; plots; characters

\section{INTRODUCTION}

Nowadays with the quick updating of mass media, movie culture is becoming popular among people, and young learners in university campus are no exception. They prefer watching movie versions to reading the literary works in paper products. As an English literature teacher, we can make the full use of this situation to arouse students' interests in learning literature and attract them to go back to read the original literary texts if they want to know more details or the difference between movies and the texts. Charles Dickens' "Great Expectations" has been adapted many times which attracts some researchers' attention, such as Wang Xin[1], Li Shuqing[2], Dong Jinquan \&Liu Shiang, [3],Yang Yansheng \& Sun Bo[4],and Ye Zhou[5], etc.. Almost all of the researches mainly focus on the level of text analysis or movie interpretation. As a result, the research into the text or novel from the teaching literature angle is seldom discussed. In the following parts, I will set an example for teachers to imitate by choosing Charles Dickens' "Great Expectations" and the adapted movie version in 2012 to compare in order to show their differences in characters and plots. The author of this paper hopes this way of teaching literature can arouse students' interests in learning literature and attract them to go back to read the original literary texts.

\section{THE DifFERENCES IN CHARACTERS AND THEIR RELATION}

\section{A. Orlick}

In chapter15 of "Great Expectations", readers meet the male character Orlick who is described like this: "Joe kept a journeyman at weekly wages whose name was Orlick. But he was a fellow of that obstinate disposition...He never even seemed to come to his work on purpose, but would slouch in as if by mere accident[6]107... this morose journeyman had no liking for me.” [6]108 From above description, readers can draw the following conclusion about Orlick's personality: idle, lazy, obstinate, morose, and asocial. These negative personal traits of Orlick may give readers some hints about the two events going to happen in the later chapters, which shows Orlick's great importance to the development of the plots. The first event was that he killed Pip' sister. The original story goes like this: Orlick worked in Joe's forge and was bored with Pip's sister's blame and curse. One day, when Pip asked Joe to give him half day's holiday, Orlick asked for the same thing. Just then, Pip's sister heard what happened, she immediately scoped Orlick, which made him very angry. Later, for revenge, he killed Pip's sister without be revealed. The other was that Orlick intended to kill Pip, but failed in the end. The original story goes like this: A note came to Pip before Pip wanted to help Magwitch to escape successfully. Then Pip did what according to the note. Afterwards he was attacked and the attacker was Orlick who thought it was Pip who made his life miserable. When Orlick prepared to kill Pip, Pip's two friends Herbert and Startop rushed in and stopped the murder. The first thing gave a clear reason about Pip's sister's death, whose death made the relation between Biddy and Joe having a further development. The second thing caused the main character Pip's fate to become more dramatic, which not only let the plot to reach a climax but also showed the sincere friendship among Pip and his friends Herbert and Startop.

Whereas in the adapted film, there was no Orlick. Joe just had Pip for help, and Mrs. Joe Gargery only appeared when Pip was young. After Pip grew up, Mrs. Joe Gargery suddenly disappeared. The film didn't explain where she was and whether she was alive or dead. So in the film, on the one hand audience could not feel Mrs. Joe Gargery's deep love in her heart to her husband and her brother, one the other hand the movie would not make audience have a reasonable explanation about her disappearing. As a result she would leave a wicked 
and ugly impression to audience. At the same time, the plot that Joe fell in love with Biddy and they married in the end would also puzzle audience.

\section{B. Other Characters}

In the novel, some other characters such as Matthew Pocket, Mrs. Pocket and Startop were also worth readers' attention. Matthew Pocket was Herbert's father. He was described like that: "Mr. Pocket was a gentleman with a rather perplexed expression of face and with his very grey hair disordered on his head...When he had talked with me a little, he said to Mrs. Pocket, with a rather anxious contraction of his eyebrows, which were black and handsome, 'Belinda, I hope you have welcomed Mr. Pip?’'[6]179 Mr. Pocket was Miss Havisham’s cousin. He was the only one who was ever against the marriage of Miss Havisham and told her Campeyson was a liar. From these description about Mr. Pocket, we can see Mr. Pocket is a real gentleman who has the warmth and kindness to his young guest, Pip. On the contrary Mrs. Pocket in the novel was described as a hypocritical person: she was a worshiper for nobles' life. She made up a noble background for herself and was al ways immersed in the made-up story so that she believed it was true. She never cared about household duties, even her children. Thus the images of Mr. Pocket and Mrs. Pocket in the novel formed a sharp contrast. Having agreed on the tradition that men worked out and women cared affairs at home and obeyed their husbands' orders, Charles Dickens often expressed his idea that women did not care about household duties, which led to unhappy families. As for Startop, he studied with Pip at Mr. Pocket's. Except for Herbert, he was the most reliable friend to Pip. As was mentioned above, he and Herbert saved Pip and helped Pip to send Abel Magwitch away.

Whereas in the adapted film, due to limited time and space and the director's own point of view as well, audience can only have a glimpse that Mr. Pocket and Mrs. Pocket were just shown when Herbert told Miss Havisham's wedding to Pip. As for Herbert's background, it was not mentioned at all in the movie and as a result, audience loses a chance to feel the charm and comic effect brought by the couple. Similarly Startop was deleted in the movie because Magwitch was sent away just by Pip and Herbert.

\section{The Differences IN Plot}

Among all the films adapted by classic novels, there is no one which can perfectly tell the story in the novel, and "Great Expectations" is no exception. It was cut into a film about two hours,so some plots were surely deleted or changed. The following parts show the differences at Pip's three stages.

\section{A. Pip Being a Young Boy}

In the novel, there is a plot like this: One day, Pip went to take Joe back from the village pub where he met a stranger. The stranger told Pip another man asked him to give Pip two pounds, which reminded Pip of the criminal that he helped once. At that time, Pip felt that having criminal friends made him more humble than ever. After that, the criminal Magwitch came to find him, Pip was so shamed and thought that Magwitch came to him for those two pounds, so Pip gave the same two pounds to Magwitch and hoped he could leave immediately. The second plot was that Pip's sister was attacked, which was mentioned above. After Pip's sister was attacked, Biddy came to live with them and looked after this family, which was a point that promoted the further development of the relation between Biddy and Joe.

However, in the film, these two plots were not shown. Instead, Pip's childhood was described in the film by three main plots. One was Pip's life with his sister and Joe. The second was that he met Magwitch who would offer him a great expectation in the future. The last one was that Pip had a chance to accompany Miss Havisham in the Satis where he began to change his attitude to life and he met four important people who affected his fate- Miss Havisham, Estella, Herbert and Mr. Jaggers.

Compared with the original, the film did not show the plot that the stranger gave Pip two pounds due to Magwitch's requirement, so it was less reasonable and unexpected in the film that Pip wanted to use two dollars to send Magwitch away.

\section{B. Pip Growing Up}

Many plots in the novel are listed here: After Pip had worked as the apprentice for Joe for four years, a surprise came to him and would change his life. When Joe and he were sitting in the pub, listening to Mr. Wopsle who was dramatically reading a newspaper report of a murder trial, a stranger disturbed them. That man was Mr. Jaggers who came to find Pip. Pip was informed that he would be able to receive education with the help of a stranger and inherit a fortune from that man. When Pip went to town to order his new clothes and prepared for going to London, Mr. Pumblechook had already made the preparation well to welcome him. They drank wine together and Mr. Pumblechook intentionally mentioned what he did for Pip. After Pip was familiar with Herbert, Herbert introduced him to his father in Hammersmith where Pip paid a visit to all Herbert's family members. And Pip spent some months studying hard with Mr. Pocket. Except for Pip, there were two other men studying at Mr. Pocket's--Bentley Drummle and Startop. This was the first time Pip met Bentley. In the novel, only four men were invited to dinner by Mr. Jaggers, and they were Startop, Drummle, Herbert and Pip. Later, Joe came to invite Pip, and they had breakfast with Herbert together, which made Pip feel it was a painful experience. On the way to invite Miss Havisham, Pip met the man who gave him two pounds, which reminded him once again of the criminal he saved in the childhood. One evening, Pip got a letter telling his sister's death, which made Pip go back to village to attend his sister's funeral. Once Pip went to see Miss Havisham. She realized how Pip had suffered, so she asked what she could do for Pip. Pip asked nine hundred pounds for her, the sum of money was actually used to help Herbert. Then Pip left, but at that time, he had a strange feeling, which caused him to return to the room to find Miss Havisham. Yet in front of him he saw the room was surrounded by the fire, and Miss Havisham was wounded heavily in the fire but not dead immediately. Because of this Pip sent for a doctor to look after her. Later, Pip got the news that Miss Havisham died, and she left 4000 pounds to Matthew, and the rest of her fortune was to Estella. Mr. Jaggers' housekeeper was charged of murder because she was revenge for her husband. 
"and I had heard of the death of her husband, from an accident consequent on his ill-treatment of a horse. This release had befallen her some two years before; for anything I knew, she was married again.” [6]457

Joe and Biddy finally indeed married in the film, but it was not pointed out whether they had children. After eleven years, Pip saw Estella. But the plot did not happen nearby Miss Havisham's old house. It was shown like this: one day, when Pip was working at Herbert's company, Herbert's son delivered a letter to Herbert. After Herbert saw the cover of the letter, he found it was from Estella. Later, Pip went to a place which offered people to relax. When Pip walked into the place, he saw Estella. Estella told him her husband died two years ago, without mention her second marriage. Then they expressed their own love to each other. The following dialogue showed it:

----You are a part of me, Estella.

----You said I was in the ships and the rivers.

----I love you, Estella.

----I'm glad.

In the novel, Biddy was a perfect female image Charles Dickens created. She was smart, competent, kind and considerate. She looked after Pip's sister, persuaded Pip to give up that unrealistic dream and understood and respected Joe's passion for his work. In the end, she and Joe got married after the death of Pip's sister[7]238, and they had a happy life together. By describing Biddy, Charles Dickens wanted to express his idea that only the female fulfilled their duties in the family and performed virtue belonging to them, could they live a happy life. This plot more convincingly demonstrated Charles Dickens' idea about the role of women in the family. Whereas in the film, even though Biddy married Joe, the plot that Biddy, Joe and their children happily sitting by the fire could not been shown. So compared with the novel, the film could not tell it better. Marrying Estella was a part of Pip's great expectations. After the end of the novel, Pip and Estella demonstrated their relation by saying they were friends. Estella had been married again, and she and Pip could not been together forever, which just gave the emphasis to one of the motifs of the novel-disillusion of Pip's great expectation dream. But in the end of the film, both Estella and Pip's dialogues and their expressions made audience an impression that they loved each other deeply and they would marry, which diminished the strength of this novel to cater for the audience's expectation of a happy ending.

\section{CONCLUSION}

Because the year 2012 is Charles Dickens' birthday anniversary of 200 years, the adapted film "Great Expectations" in 2012 was given much attention from many literary lovers after it was on. The film realistically presented us the social environment of that time in the novel and the main character Pip's growing experience in body and mind, yet when we make a comparison between the novel and the film in plots and characters, we can find that the original was adapted too much. To make audience know those classic novels in the world in a convenient and fast way, film directors try their best to show the original in a short time. And on the premise of ensuring the same theme, they certainly revise some parts of the novel, which is inevitable. In any way, movie is an 
interesting way to be used to introduce classic works to students, but after watching the adapted film, students should estimate the films with a dialectical and critical view. If they really love literature, they shouldn't only know about it through the adapted version, instead they should go back to read the original.

\section{REFERENCES}

[1] W. Xin. "From 'Great Expectations' to Its Movie Version: the model of novel being adapted into film," in Language Literature and Art, Vol. V, S. Weihua, Eds. Hangzhou: Journal of Zhejiang Gongshang University, 2012, pp.75-79.(in Chinese)

[2] L. Shuqing. A Vivid Picture of British Social History in the 19th century-“Great Expectations," Vol. I, Hebei: Hebei Education (comprehensive edition), 2006, pp. 46-47.(in Chinese)
[3] D. Jinquan, L. Shiang. "Analyzing the Female Characters in 'Great Expectations'," in Culture and Art, Vol. XXIV, Y. Zhixiang, Eds. Chongqing:Journal of Chongqing Science and Technology Institute (social science edition), 2012, pp.119-121.(in Chinese)

[4] Y. Yansheng, S. Bo. "Realistic Style and Aesthetic Tendency -- Probing into Two Films Based on 'Great Expectations',' in literature, Vol. XXIII, S. Xiaoqing, Eds. Nanjing: Material of culture and education, 2005, pp.131-132.(in Chinese)

[5] K. Depengna, Y. Zhou(trans.). "Seizing Time, Losing Time, the Sudden Change of Plots in David Lean's Great Expectations," in Movie Review, Vol.VI, H. Jialing, Eds. Changchun: World film, 1997, pp.100-115.(in Chinese)

[6] D. Charles. Great Expectations. Beijing: Foreign Language Teaching and Research Press, 2001.

[7] L. Yiqing, L. Jiong. A Brief History of English Literature. Beijing: Foreign Language Teaching and Research Press, 2008. 